\title{
Benchmarking Management Education in India
}

\author{
Ravi BS, Dr. Sumathi GN \\ Research Scholar at VIT Business School, VIT University, Vellore, and Chief People Officer of Vinayaka \\ Missions University \\ Associate Professor at VIT Business School, VIT University, Vellore
}

\begin{abstract}
The paper examines the current status of management education in India and the quality of such education. It looks at the concept of management education, benchmarking, and growth of MBA courses in India. It suggests methodology for benchmarking to improve the quality of the institutions and effectiveness of students coming out of the B-Schools. The paper also captures recommendations that would help to improve the quality of management education in India. It reviews the data from Indian Regulatory Authority, All India Council for Technical Education (AICTE), and the principles of the US accrediting body, Association to Advance Collegiate Schools of Business (AACSB)
\end{abstract}

Key Words: Management education, Benchmarking, MBA, AICTE, AACSB,

\section{Management Education:}

Management education is a multidisciplinary study. For instance certain studies in marketing management could draw upon economics, behavioural sciences, and technologies. Management education intends to develop analytical, diagnostic and problem solving skills of the students. The education provided has to keep pace with changes in business enviornment.

In addition to traditional classroom lectures, MBA courses are based on assignments, projects, and live problems. It is important to employ teaching methods involving case method, role play, and business games.

\section{History of Management Education in India:}

The first MBA course was initiated in 1954 by Indian Institute of Social Welfare and Business Management at Calcutta. Prior to that, Tata Institute of Social Sciences, Bombay, ( 1936 ) and Xavier Institute of Labour Relations, Jamshedpur, ( 1946 ), were offering executive programmes to managers. Thereafter, at the instance of the Planning Commission of India, a Ford Foundation initiative resulted in a report on management education by Dean Robbins. Based on this exercise, Indian Institute of Management (IIMs) were established Calcutta in 1961, Ahmadabad in 1962, and Bangalore in 1972. Post 80s with liberalisation of economy including the education sector, has resulted in proliferation of institutions offering MBA programmes, increasing the quantity with less focus on the quality. Table 1 below indicates the huge growth in MBA education - the data by AICTE (All India Council for Technical Education) excludes deemed universities programmes and institutes of national importance like the IIMs.

\begin{tabular}{|l|c|c|}
\hline \multicolumn{3}{|c|}{ Tahle 1 } \\
\hline Year & Mgt. Institutions & $\begin{array}{l}\text { Mgt. Students } \\
\text { Strength }\end{array}$ \\
\hline $2006-07$ & 1132 & 94704 \\
\hline $2007-08$ & 1149 & 121867 \\
\hline $2008-09$ & 1523 & 149555 \\
\hline $2009-10$ & 1940 & 179561 \\
\hline $2010-11$ & 2262 & 277811 \\
\hline $2011-12$ & 2385 & 352571 \\
\hline $2012-13$ & 2467 & 385008 \\
\hline
\end{tabular}

It should also be noted that there are some 300 plus institutes whose MBA programmes have not been approved by AICTE (AICTE website)

\section{Current Status - Deficiencies:}

Indian management institutions have been found to be deficient in global perspective, leadership skills, recognising organisational realities, acting innovatively, thinking critically, communicating clearly, and in understanding the limitations of models and markets (Datar, Garvin, \& Cullen, 2010). 
In Indian MBA schools teachers are appointed on contract. They have limited opportunity for interaction with the student community to develop the overall personality of the students, and groom prospective managers for the corporations. Research carried out by MBA departments in universities is extremely limited,

\section{Benchmarking:}

Benchmarking involves identifying competitors and / or companies in other industries that exemplify best practice in some activity, function, or process and then comparing one's own performance to theirs (Robert G Eccles, 1991).

The policy perspective committee on management education ( 2000 ) while looking to improve quality of management education, looked at preparation of course, admission process, transparency in examination, review of course and programmes at regular intervals, short programmes for executives, and governance mechanism.

While benchmarking management education one could look at rankings of management institutions done globally. Amongst others, business journals, Financial Times, Forbes, and Economist, carry out their own study, and publish the rankings of MBA institutions, every year. TIMES World University Rankings is another global study that covers universities, including those that offer MBA courses. Only IIM Ahmadabad has found a place at $48^{\text {th }}$ Rank in Economist listing of international MBA courses.

One should also look at accreditation by AACSB (Association to Advance Collegiate School of Business) as a benchmarking standard. AACSB has a rigorous self evaluation followed by peer review elements, covering 15 business standards. They look at institution mission statement, customer satisfaction, technology, public responsibility, strengths, attitude to employees, organisational outcome, and involvement of stakeholders as factors for assessment. Unfortunately, amongst the multiple business schools in India, only three have accreditation of AACSB, viz., IIM - Calcutta, ISB. Bengaluru, and T.A.Pai Institute of Management, Manipal.

The National Knowledge Commission 2006-2009 has made significant recommendations based on an extensive study, based on expert consultation, which had obviously taken in to consideration best bench marked practices. These included:

1. Board of Governors selection to be transparent with $50 \%$ independent directors

2. Establish standing committee for management education to govern MBA institutions

3. Encourage faculty to develop India centric case studies

4. Mandatory rating of all MBA institutions by credit rating agencies like CRISIL and ICRA

5. Increase weightage for work experience in student intake

6. Compulsory practical apprenticeship with companies as part of the course

7. Board to encourage higher publication by faculty in journals

8. Method to obtain student feedback on teaching - learning process

9. Introduce special programmes to cater to Agriculture, Rural Banking, Service Sector and the like

10. Obtain recruiters feedback to improve quality of students

11. Provide scholarship to disadvantaged students

12. Establish autonomous institute for faculty development

13. Leading MBA institutions should mentor 3-4 other MBA schools for up gradation of quality

\section{Recommendations to Improve Quality:}

The recommendations based on work already done to which references have been made in this article, and metrics used by organisations that rank MBA schools, would include:

1. Autonomy to business schools and minimising the current trend of the regulatory authorities to look for uniformity in MBA courses

2. The education has to be more student centred and less oriented towards class-room education

3. Programmes would have to be compulsorily residential as it would help in over all personality development of the students

4. Institutions would have to put technology to extensive use, making available digital library with access to research articles to promote meaningful self study by the students

5. Institution Industry interface has to increase in different dimensions like research, internship, joint development of curriculum, etc.

6. Emphasis on field work and practical exposure in an intense way as practised by institutions like TISS have to become part of the design of the MBA courses. Students should have real time exposure at least for one term in a two year programme

7. Institutes should align with a global economy by increasing the number of international citizens as part of the community of the institution - both teachers and students

8. Increase the diversity of the MBA class composition - currently the number of students coming from engineering stream largely outweigh students from other streams 


\section{Conclusion}

Indian economy has been growing and as a member of Brazil, Russia, India, China, and South Africa group (BRICS) and the growth would require managers for varied enterprises. Indian managers are also required abroad with the spread of industries outside India, post liberalisation and globalisation. Quality of MBA graduates and MBA institutions have to be improved based on recommendations in this paper and other studies to fulfil requirements of a growing nation.

\section{References:}

[1]. Dayal, I. (2003), Development of Management Education in India, Journal of Management Research, 2(2), 98-113

[2]. Jha,S., \& Kumar,M. (2012), Revitalising Management Education in India - A Strategic Approach, Journal of Management and Public Policy, 3(2), 5-11

[3]. Kalpana, S. (2013), Quality Parameters of Management Education in India, Srusti Management Review, 6(1)

\section{Web Sources:}

[4]. Www.aicte-india.org

[5]. www.aacsb.edu 